\title{
On Rural Legal Needs and Service Mode
}

\author{
Haixia Wang \\ Tonghua Normal University, Tonghua, 134002, China
}

\author{
Keywords: Rural law, Service mode, Legitimate interests, Related research
}

\begin{abstract}
Now, under the background of more and more pressing legal needs in our country, the poor status of legal services makes the rights and interests of rural residents have not been well maintained, and therefore explicit rural legal needs and reasonable and standardized implementation of the rural legal services are necessary. Based on this point, from the perspective of the need for legal services in rural areas, make an analysis on rural legal needs, thereby exploring mode of rural legal services, hoping to help optimize the implementation of the rural legal services.
\end{abstract}

\section{Introduction}

Providing good legal services for the majority of our peasants is an important precondition of law-governed agriculture. But at present, the rural legal service system in China is experiencing reform and perfection. Undeveloped rural economy, huge influence of traditional culture, weak awareness of the law and other factors result in poor status of legal services in rural areas, not able to effectively maintain the legitimate rights and interests of peasants. In this regard, the author proposes from the perspective of understanding the rural legal needs, to explore the legal service mode suit for rural areas for rational, standardized and effective legal services in rural areas, thus better safeguarding the legitimate rights and interests of peasants, to promote China gradually to walk towards a legalization country.

\section{Necessity of rural legal service}

Grassroots government by law has the basic, exploratory and guiding role in the legal construction in the whole country. In order to promote China to walk towards in the direction of legalization, under the condition of constant improvement of the legal system in our country now, it is essential to pay much attention to strengthening rural legal services.

\section{Maintain and protect legitimate interests of disadvantaged groups}

In the "Communist Manifesto", Marx and Engels pointed out, "The first step of worker revolution is to make the proletariat as the ruling class, to win democracy." This fully shows that the grassroots is the prerequisite condition to push the country to really walk towards a socialist country. In order to achieve democracy, socialist legislation, it is necessary to pay attention to legal services in rural areas, which can make disadvantaged groups protected by law, safeguard their legitimate rights and interests, so that they can live well under the legal protection. Rural legal services represent the eager hope of our Party to achieve democracy and enable people in rural areas to enjoy their rights as masters of the country and protect their interests in case of infringement. Therefore, in the new era, under the background of progressive development of rural economy, and gradual increase of peasants' awareness of the law, it is extremely urgent to actively implement the rural legal services.

\section{Publicity of legal system in China}

The saying goes that "no rules, no standards". China is a legalization country, and any person, any organization must follow the law, and orderly conduct activities. China is still in the primary stage of socialism, Legal awareness and master of legal knowledge of national people are not very clear and precise. This situation is not conducive to the effective implementation of our legal system, but also not to the legalization construction. It can be seen that from the current level of legal awareness and master condition of legal knowledge of people, the residents in the rural areas have poor legal 
awareness and little legal knowledge. Legal services carried out in rural areas can publicize and explain the legal knowledge to peasants, enhance the legal knowledge and legal awareness of peasants, making them conduct agriculture and other activities according to the law, and pay attention to protect their legitimate rights and interests. Rural grassroots system is an integral part of our legal system, and development of rural legal system can strengthen our legal system construction, and create conditions for the legalization construction. Legal services in rural areas will promote our legal system to a certain extent, and also promote the construction of the legal system in China.

\section{Guarantee judicial justice}

Judicial justice is the ultimate goal pursued by Office of Justice. Guarantee of justice can ensure that in the process of seeking legal help, our citizens can make a fair judgment, so that the interests of victims can be protected. And in terms of rights protection of our people, rights and interests of rural residents is the most difficult to be protected. The first reason is that peasants have weak legal awareness; the second is approaches for rights protection for peasants are limited; the third reason is the injustice encountered by peasants. There are many factors which make more difficult for peasants get fair and impartial judicial results. But the effective implementation of the rural legal services can provide assistance to peasants who seek legal help, collect legal information and make legal events indictment for peasants, thus reducing or even eliminating the unfair treatment, in order to achieve justice. This fully shows the effective implementation of rural legal services.

\section{Perfection of grassroots social security system}

At present, the social security system in rural areas of China includes rural social insurance, rural social assistance, rural social welfare, and rural special care and so on. Under the background of growing aging population in China, pension and medical insurance for rural residents are in bad need. Legal services in rural areas can introduce social security system to peasants, and enable peasants to protect their own interests in accordance with the requirements of the social security system. In order to enable peasants to protect their own interests in accordance with the requirements of the social security system, the social security system needs to continue to be improved and optimized to clearly explain legal terms that peasants urgently want to understand. Therefore, the implementation of rural legal services indirectly can improve the basic social security system.

\section{Analysis on rural legal needs}

\section{Resolve disputes resulting from civil legal relationship}

In rural areas, in the daily life, legal disputes often encountered by peasants mainly include will distribution, property inheritance, marital property agreement, family and neighborhood disputes, loan disputes, damage disputes and other traditional civil disputes. At present, legal awareness of peasants is increasing, and rural residents also pay attention to protect their legitimate rights and interests in the event of disputes. However, due to the limited financial resources and very few legal institutions, it is more and more difficult to settle civil dispute through legal channels. So, from this point of view, rural residents have a true and clear need for the law.

\section{Resolve disputes resulting from economic legal relationship}

As China's economy continued to improve, some companies and factories cooperate with rural governments to create the economy together. Rural residents will rent a lot of lands to companies and factories, so that they can build plants or office buildings. A large number of local rural enterprises are established. For seeking economic benefits, or hiring local peasants, creating rural economic cooperation, probably due to some factors during the development of rural enterprise some disputes will occur, such as labor disputes, rural economic cooperative legal issues. To effectively resolve legal disputes in rural areas, we need professional and responsible legal institutions, but very few legal institutions in rural areas make economic legal disputes become one of key factors affecting rural normal and orderly development. Today our country is developing well, and strengthening rural 
legal services can help rural residents to solve economic legal disputes. Therefore, on the basis of a certain legal awareness, the legal need of rural peasants is very large.

\section{Legal needs in the daily life}

Self-government is implemented in rural areas. The organization of self-government is the villager committee, which is not only the autonomous organization but also to assist grass-roots government to fulfill administrative responsibilities, with some administrative quality, and economic organization function. But lack of legal knowledge results in that peasant cannot safeguard their rights and interests in case of infringement, especially in their daily lives, rights protection is more difficult to achieve. In the daily life, rural work to be dealt with is complicated, disputes resulting from land contracting, village planning, life ditches excavation and others may occur, which results in a lot of legal risks in their daily life. Upholding the idea of serving peasants, the implementation of legal services in rural areas can help the village committee to resolve legal disputes and create conditions to protect the legitimate rights and interests of peasants. So, from the above point of view, demand for rural law is strong, and there is an urgent need to rationally use law to resolve disputes or problems.

\section{Analysis on rural legal service mode}

Based on above analysis, it can be fully showed that the rural legal services are significant, which will not only help peasants to solve their disputes arising in the life, but also enhance the legal awareness of peasants, and promote our legal system construction, so that China continues to develop in the direction of legalization. To achieve the effective implementation of the rural legal services, we need to use the appropriate legal service mode.

\section{Implementing rural grassroots legal service through establishment of people-oriented concept}

Effective implementation of the rural grassroots legal service work is very meaningful. But to achieve effective implementation of rural grassroots legal service, it is inevitable to optimize legal services mode. In view of our current situation in rural areas, in order to effectively implement the legal service mode, it is necessary to establish the people-oriented concept. Focus on serving peasants, respect peasants, care about peasants, put the interests and needs of peasants in the first place, scientifically, rationally and effectively plan and implement the rural grassroots legal services, promote targeted legal services, solve problems of peasants, and protect legitimate rights and interests of peasants. Therefore, it is particularly necessary to establish the "people-oriented" concept to conduct rural grass-roots legal services.

\section{Implement rural grass-roots legal services through popularization of rural grass-roots legal knowledge}

Faced with the current status of poor level of rural legal services in China, we should through optimization select legal service mode, from the perspective of serving peasants, regularly and reasonably implement legal services, in order to effectively solve problems of peasants, and enable peasants to protect their legitimate rights and interests. The rational use of legal services mode requires legal service mode in the application process, can popularize rural grassroots legal knowledge, improve the legal knowledge level and legal awareness of peasants, and enable them to protect their rights by law in the face of difficulties or problems. So, how to popularize legal knowledge to peasants? The author thinks that we should gradually affect peasants through publicity and education. Publicity of legal knowledge can gradually make legal knowledge impressed in people's minds, and explanation of legal knowledge to peasants through disputes enable peasants to grasp legal knowledge and also know how to use legal knowledge, so that they can use legal knowledge to protect their rights in life.

\section{Implement rural grass-roots legal services through establishment of legal service team}

At present, in China, rural grassroots legal service team is mainly composed of a few law firms and lawyers, judicial staff, police staff and village cadres. From the perspective of rural legal needs, the 
current construction of rural grassroots legal team is not perfect. Few staff, weak legal foundation, inadequate capacity and other issues exist, which will affect the level of rural grassroots legal service to some extent. Therefore, in order to ensure optimize implementation of rural legal services, we should at the national level select related staff with noble ideological level, strong ability, professional skills, and good quality, and then form rural grassroots legal service teams, able to ensure justice and reason when dealing with rural legal disputes so as to effectively solve disputes and protect the legitimate rights and interests of peasants. So, in terms of optimization and selection of rural legal services mode, pay attention to analyze whether the implementation of the legal services mode has a legal service team, expecting to strengthen rural grassroots legal service team through the implementation of legal service mode, so that it can full play its role in legal services.

\section{Implement rural grass-roots legal services through perfection of legal service system}

Although the construction of the legal system in China has made outstanding achievements, but the rural grassroots legal system construction has many problems, which results in that legal services fail to address the needs of peasants, and to be implemented regularly and reasonably. In this regard, we should adjust and optimize the rural legal services related aspects through the improvement of rural grassroots legal service system. For the construction of rural grassroots legal service system, firstly determine the central status of rural grassroots legal service; secondly separate it from judicial administrative departments, ensuring that it is truly for the purpose of legal services. Finally, based on the current rural situation, and related laws and regulations, develop practical rural grassroots legal service system.

\section{Conclusion}

For the urgent rural legal needs at present, the author thinks rural grassroots legal service mode should be optimized through establishment of the people-oriented concept, popularization of rural grassroots legal knowledge, building legal service team, perfection of legal service system to make sure the scientific and rational implementation of rural legal services, protect the legitimate rights and interests of peasants, and also promote the development of legalization in our country. Therefore, under the background that more and more importance is attached to the legal system construction, it is significant to actively build grassroots legal system in rural areas and effectively implement the rural legal services. Only when the legal level of peasants is enhanced, can China be promoted to walk towards legalization.

\section{References}

[1] Zuo Lihua, Zhou Rongwei. On status and countermeasures of grass-roots employment oriented college graduates. Overseas and Employment. Employment and Education, 2012 (1), 23-26.

[2] Li Yuhua, Jian Anna, Wen Yuanhong. Philosophical thinking of rural grassroots legal aid value. Realistic. 2011.01: 208-209.

[3] Liu Xiaolan. Experience of foreign legal aid and perfection of Chinese legal aid system. Journal of Hunan Agricultural University (Social Science Edition), 2008 (2): 106-108.

[4] Fang Yaqing, Ying Minchun. On dilemma and direction of rural legal publicity and education in the period of social transformation. Social and Legal System, 2010 (9) (bottom): 229-230.

[5] Zhang Yunling. Analysis on the legal aid system in the new rural construction., Journal of Hefei College (Social Sciences).2012 (29): 109-111. 